This item was submitted to Loughborough's Research Repository by the author.

Items in Figshare are protected by copyright, with all rights reserved, unless otherwise indicated.

\title{
Exploring spillovers between government quality and individual health production through sport and physical activity
}

PLEASE CITE THE PUBLISHED VERSION

http://dx.doi.org/10.1080/16184742.2016.1257038

\section{PUBLISHER}

Taylor \& Francis ( E) European Association for Sport Management

\section{VERSION}

AM (Accepted Manuscript)

\section{PUBLISHER STATEMENT}

This work is made available according to the conditions of the Creative Commons Attribution-NonCommercialNoDerivatives 4.0 International (CC BY-NC-ND 4.0) licence. Full details of this licence are available at: https://creativecommons.org/licenses/by-nc-nd/4.0/

\section{LICENCE}

CC BY-NC-ND 4.0

\section{REPOSITORY RECORD}

Wicker, Pamela, and Paul Downward. 2019. "Exploring Spillovers Between Government Quality and Individual Health Production Through Sport and Physical Activity". figshare. https://hdl.handle.net/2134/22921. 
Exploring spillovers between government quality and individual health production through sport and physical activity

\author{
Pamela Wicker $^{1}$ and Paul Downward ${ }^{2}$ \\ ${ }^{1}$ German Sport University Cologne \\ ${ }^{2}$ Loughborough University
}

\title{
Contact details
}

Pamela Wicker, Department of Sport Economics and Sport Management, German Sport University Cologne, Am Sportpark Muengersdorf 6, 50933 Cologne, Germany; Phone: +49-221-4982-6107; Fax: +49-221-4982-8144; E-mail: p.wicker@dshs-koeln.de; Paul Downward, School of Sport, Exercise and Health Sciences, Loughborough University, Leicestershire, Ashby Road, LE11 3TU, UK; Phone: +44-1509-226365; Fax: +44-1509223935; E-mail: p.downward@lboro.ac.uk.

Correspondence concerning this article should be addressed to Pamela Wicker, Department of Sport Economics and Sport Management, German Sport University Cologne, Am Sportpark Muengersdorf 6, 50933 Cologne, Germany; Phone: +49-221-4982-6107; Fax: +49-221-4982-8144; E-mail: p.wicker@dshs-koeln.de

\section{Acknowledgements}

The authors would like to thank Manuel Herter for his excellent research assistance.

Disclosure statement

This research received no specific grant from any funding agency in the public, commercial, or not-for-profit sectors. 
Exploring spillovers between government quality and individual health production through sport and physical activity 


\begin{abstract}
Research question: The purpose of this study is to examine whether and how government quality is related to individual health production through sport and physical activity. Previous research has only examined the role of government through the lens of government spending and provision of facilities, but not the role of government quality per se.
\end{abstract}

Research methods: Individual survey data from the 2013 Eurobarometer $(n=20,419)$ were combined with data on government quality and expenditure as well as GDP for 21 European countries. The sport and physical activity measures reflect whether an individual's activity level (including or excluding walking) is below the guidelines of the World Health Organization, meets, or exceeds them, securing extra health benefits.

Results and findings: The results of multi-level models show that government quality is significantly and positively associated with individual sport and physical activity meeting or exceeding the guidelines, controlling for GDP and government spending. The empirical evidence suggests that there are spillovers between government quality and individual health production through sport and physical activity.

Implications: The findings indicate that a more open and accountable government can provide the regulatory framework and tolerance required for more effective structural delivery of sport and physical activity in society.

Keywords: Europe; government; policy; sport participation; health 


\section{Introduction}

The current policy environment connected with sport and physical activity is dominated by two narratives. The most persistent of these is that obesity is a global concern for public health (World Health Organization [WHO], 2000). Research shows that obesity is associated with various health problems including, for example, an increased risk of heart failure (Kenchaia et al., 2002), liver cancer (Larsson \& Wolk, 2007), replacement of joints (Liu et al., 2007), and other chronic diseases such as hypertension and diabetes (WHO, 2000). One way to reduce obesity is to participate in sport and physical activity which can be considered an investment in health production (Downward, Dawson, \& Mills, 2015; Mullahy \& Robert, 2010). In addition to reducing obesity, participation in sport and physical activity has further health benefits including a reduced incidence of high blood pressure, heart disease, asthma, and arthritis (e.g., Blair, 2009; Humphreys, McLeod, \& Ruseski, 2014; Warburton et al., 2006).

Increased sport and physical activity is therefore recommended by the WHO (2000, 2010) as a policy objective and, consequently, the European Union and its member states have demonstrated a growing interest in the fight against obesity (Department for Culture, Media and Sport [DCMS], 2002; HM Government, 2015; Kurzer \& Cooper, 2011). Governments have taken various measures to promote participation in healthy behaviour and sport and physical activity, respectively. For example, they try to promote the latter through spending on sport programmes and facilities in order to make physical activity accessible and affordable for all population groups (e.g., Wicker, Breuer, \& Pawlowski, 2009). Such government expenditure has targeted all levels including the community level (Wicker, Hallmann, \& Breuer, 2013), regional level (Kokolakakis, Lera-Lopez, \& Castellanos, 2014), and national level (Downward, Lera-López, \& Rasciute, 2014). This multi-level approach is 
in line with the claim by Lang and Rayner (2005) who stated that in order for obesity to be reduced, multi-level analyses and interventions are required.

Another narrative is connected with the integrity and governance of the organisations connected with sport and physical activity. For example, the recent scandals associated with financial irregularities in the Fédération International de Football Association (FIFA) (Bean, 2016) and doping in athletics (Mather \& Clarey, 2015) have highlighted the importance that sport has in the public conscience, and run counter to the message that elite sports can be used as a vehicle for the public promotion of sport and physical activity (DCMS, 2002). For example, the 2012 Olympic and Paralympic Games were promoted on the basis of inspiring a nation to participate in sport (TNS BMRB, 2012). This is despite the fact that such claims have not been substantiated by research examining the participation legacies of major sport events, and particularly so for new sport participants (Weed et al., 2015). More fundamentally, organisations like the United Nations identify sport as an important vehicle for promoting inclusion, democracy, and peace (United Nations, 2016).

From an economic theoretical perspective, such arguments are based on the concept of externalities. This means that the costs and benefits effects of activities like sport and physical activity spill over to wider society and are, thus, often called upon in policy promotion (Downward, Dawson, \& Dejonghe, 2009). Not surprisingly, therefore, current European and national policy makers place importance on the need to promote democracy, transparency, and accountability in sport. This is currently manifest in European Union (EU) actions of sport (European Commission, 2016) and also forms a centre piece of recent UK government physical activity promotion (HM Government, 2015).

What is never actually addressed in policy discussion, however, is the potential role that government integrity in itself could have on policy outcomes. Logically, as the key stakeholder in the development and promotion of policy, spillovers from their integrity can be 
expected to be part of the chain by which outcomes in society vary according to policy initiatives. It follows that whilst there is justifiable concern over the integrity and governance of sport organisations, the current crisis with FIFA (Sydney Morning Herald, 2015) shows that scrutiny should (and will) also fall on governments whose reputation may suffer in the absence of public confidence in their integrity (New York Times, 2015).

The focus in research, however, tends to be upon government as a provider of resources more than values. Consequently, some studies have examined the conditions under which the public or private sector provision of welfare services, including health is preferred by individuals in society (Berens, 2015). Some have focussed on the way in which good governance at the level of the state can come to reflect dominant perspectives on economic policy (Roy, 2005). Other studies have specifically focussed on the effects of different types of government-related spending and measures at various levels (e.g., country, state, community level) on sport and physical activity as a component of health provision (e.g., Humphreys \& Ruseski, 2007; Lera-Lopez, Wicker, \& Downward, 2016; Wicker et al., 2009). In this latter case one question that has not yet been addressed is, to what extent does the actual process of government contribute to the promotion of sport and physical activity and, consequently, to have an impact on the outcomes of policy that it champions?

The purpose of this study is to examine the relationship between government quality and individual health production through participation in sport and physical activity. For this examination government quality data from 21 European countries, along with data on government spending and gross-domestic product (GDP), are combined with individual-level survey data. Sport and physical activity is measured with variables capturing whether an individual's activity level is below, meets, or exceeds the physical activity recommendations of the WHO (2010), the latter of which secures additional health benefits. The results of multi-level models show that government quality positively affects the likelihood of 
individuals participating in sport and physical activity with the effect being larger as we move from activity below the guidelines to activity exceeding the guidelines, controlling for government spending and GDP per capita. From a public and physical activity policy perspective, therefore, this suggests that collective dialogue between policy stakeholders that promotes integrity is important, rather than a narrative that maintains that government per se is the immutable foundation upon which it is asserted that corrective action elsewhere needs to be undertaken. This could be, for example, through government seeking to correct a lack of integrity in the sports system.

\section{Literature review and theoretical framework}

\section{Individual determinants of sport and physical activity}

The individual determinants of sport and physical activity have been widely studied (e.g., Downward \& Rasciute, 2010, 2015; Humphreys \& Ruseski, 2007, 2015). For this reason, this section only provides a short overview of the main findings. Previous studies have shown that males are more likely to participate than females (Downward et al., 2014; Kokolakakis et al., 2014; Wicker et al., 2009), although the effect was not evident in all studies (Downward \& Rasciute, 2015) or dependent on the type of activity (Humphreys \& Ruseski, 2007, 2015). Age has been found to be negatively associated with sport and physical activity (Downward \& Rasciute, 2010, 2015; Downward et al., 2014; Humphreys \& Ruseski, 2007). People with children (Downward et al., 2014; Ruseski, Humphreys, Hallmann, \& Breuer, 2011; Wicker et al., 2013) and with migration background (Wicker et al., 2013) or non-white ethnicity (Humphreys \& Ruseski, 2007; Kokolakakis et al., 2014) have been found to be less likely to participate in sport and physical activity. Research has also shown that sport and physical activity levels have varied depending on the marital status (Humphreys \& Ruseski, 2007) and the occupation and employment of the individuals (Downward \& Rasciute, 2015; Kokolakakis et al., 2014). Higher educational levels (Ruseski \& Maresova, 
2014; Wicker et al., 2013) and income have also been shown to have a positive effect on sport and physical activity (Downward \& Rasciute, 2010, 2015). It is clear that in the latter cases the indirect effects of government policy might be felt. Aspects of government policy have also been more directly investigated with respect to the infrastructure that is provided.

\section{Higher-level determinants of sport and physical activity}

At the community level, previous research has shown that an activity-friendly neighbourhood (Humpel, Owen, \& Leslie, 2002) as well as community design and access to recreational facilities can enhance participation in sport and physical activity (Norman et al., 2006). Moreover, the presence of sport facilities and in particular swimming pools in close proximity to the residents' home have been found to be positively associated with sport and physical activity (Wicker et al., 2009; 2013). This has also been the case with satisfaction with facilities (Downward \& Rasciute, 2015). That the provision of infrastructure can enhance sport and physical activity participation is not of surprise, but it need not be connected directly with government provision. For instance, in the UK there has been rapid growth in outsourcing to the private sector of previously public sector leisure facilities and an additional rapid growth of private sector facilities (Hodgkinson, Hughes, \& Hughes, 2012). What this does suggest, however, is that the policy environment in which leisure facility supply develops could have important impacts on individual behaviour as a consequence.

Turning to the regional level, previous research has examined the direct effect of government spending on participation in sport and physical activity. Humphreys and Ruseski (2007) documented that state-level spending on parks and recreation spending increased the likelihood of and time spent on outdoor recreation in the United States. In contrast, in the UK, total lottery funding and capital expenditure on sport has not been found to be significantly related with regional participation rates (Kokolakakis et al., 2014). This could be due to the 
resilience and prioritisation of government spending towards elite sport in the face of cuts to local authority services (Houlihan \& Lindsay, 2012).

At the national level, research has looked at the role of direct and indirect government spending as well as other national factors. Beginning with direct spending, sport-related spending was found to have a significant positive effect on the likelihood of participating in sport and physical activity and the frequency of participation in the member states of the European Union (Downward et al., 2014). For the same countries, Lera-Lopez et al. (2016) showed that government spending on health and education had a significant positive effect on physical activity for health with the impact of education spending being much larger. Their study suggested the presence of spillover effects from health promotion as well as the development of human capital. Similarly, van Tuyckom (2011) found that public sector expenditure on health was positively associated with participation rates in leisure-time physical activity in 27 European countries.

Turning to indirect effects, governments also spend money on elite sports, specifically on hosting major sport events and producing national sporting success, with one desired outcome being an increase in physical activity levels of the population (Grix \& Carmichael, 2012). This concept has also been referred to as the trickle-down effect (Frick \& Wicker, 2016) or demonstration effect (Weed et al., 2015). The impacts are, however, debatable. While several studies have not provided evidence of a trickle-down effect (for an overview see Weed et al., 2015), others have documented that hosting major sport events (Ruseski \& Maresova, 2014; Weimar, Wicker, \& Prinz, 2015) and sporting success (Frick \& Wicker, 2016) have increased participation in sport and physical activity.

\section{Government quality and individual physical activity}

The above literature suggests that whilst direct government targeting of physical activity through the provision and support of infrastructure may help to improve physical 
activity rates, there is equally evidence that government policy towards health and education and investment in sporting events may indirectly influence behaviours. This is indicative of direct and indirect government provisioning. However, a further channel of influence for policy that could have an effect is to provide the preconditions to which physical activity can take place. In other words it may not only be relevant to what and where governments actually commit expenditure, but also the context of values that accompanies such expenditure, or more generally permeates their governance. Thus, the quality of government and the values it conveys may influence sport and physical activity as well.

Government quality is related to the concept of governance which is defined as "the traditions and institutions by which authority in a country is exercised” (Kaufmann, Kraay, \& Mastruzzi, 2010, p. 3). The underlying concept consists of three facets each consisting of two dimensions (i.e., governance indicators). The first facet is the process by which governments are selected, monitored, and replaced, which includes voice and accountability (dimension 1) as well as political stability and the absence of violence (dimension 2). The second facet is the capacity of the government to effectively formulate and implement sound policies, which encompasses government effectiveness (dimension 3) and regulatory quality (dimension 4). The third facet reflects the respect of citizens and the state for the institutions that govern economic and social interactions among them, which includes rule of law (dimension 5) and control of corruption (dimension 6) (Kaufmann et al., 2010). Taken together, therefore, government quality can be regarded as "impartial government institutions, that is, when public officials who implement policies do not take anything about the citizen/case into account that is not beforehand stipulated in the policy or law” (Teorell et al., 2016, p. 8). This definition of governance along with the associated six dimensions has been used by various institutions (e.g., Quality of Government [QOG] Institute, 2016; Worldbank, 2016) and researchers (Teorell et al., 2016). 
The question is how and why government quality may be related with physical activity. Two possibilities suggest themselves. The first is more structural and suggests that government quality might be generally associated with the ability of a nation to meet the needs of its citizens more efficiently regardless of the specificity of their particular socioeconomic and political orientation through their regulatory approach. To be able to meet the needs of citizens, governments have to, or must be willing to, recognize the needs of citizens in a first step and act accordingly in a second step. However, in the case of government failure, such action may be compromised by politicians demonstrating opportunistic behaviour and being concerned with their re-election rather than with the citizens' needs (Downward et al., 2009; Weisbrod, 1978). Meeting citizens’ needs may require a different approach in every country. For example, it might well be that the provision of infrastructure by the local government in countries like Germany as evident in previous research (e.g., Wicker et al., 2009; Wicker et al., 2013) best meets the relevant circumstances of the country, but the same could be said of the private sector emphasis on facilities in the UK which can also promote participation (Downward \& Rasciute, 2015). The impact of infrastructure on participation is thus also channelled through the adoption of a particular, acceptable framework that provides infrastructure, rather than simply through its existence.

The second is more behavioural and suggests that government quality could be indicative of a more open, inclusive, and accountable environment in which physical activity as a form of leisure can take place. It is well-known, for example, that forms of physical activity like sport are gendered and have distinct social characteristics (Downward et al., 2015). It might be that in a society that has high levels of government quality traditional social barriers are more easily challenged and that funding does not get distorted towards being directed at secular powerful lobbies. Research has shown that the effect of government spending on health is mediated by government quality, meaning that the impact of spending 
on health outcomes is higher in countries with high levels of government quality (Makuta \& O’Hare, 2015). The latter countries are likely characterised by a more efficient use and a better allocation of available resources (Makuta \& O’Hare, 2015).

A few studies have looked at the role of government in participation in sport and physical activity, both from the perspective of economic freedom (Ruseski \& Maresova, 2014) and from the perspective of government quality (van Tuyckom, 2011). Ruseski and Maresova (2014) found that people were more likely to participate in physical activity in countries with a high degree of economic freedom and that participation rates were higher in countries with many years of female voting rights and high female labour force participation rates. Van Tuyckom (2011) documented that government quality and the six governance indicators noted earlier were positively related with leisure-time physical activity rates in European countries using data from the 2005 Eurobarometer.

Another two studies examined the relationship between government quality and health using an overall government quality index accompanied by the six governance indicators (Rabin et al., 2006) and five out of six governance indicators (i.e., political stability was excluded as it was assumed to be uncorrelated with health outcomes; Makuta \& O’Hare, 2015), respectively. Rabin et al. (2006) found that government quality as a whole and its six constituent dimensions were associated with a significant reduction in the prevalence of obesity. Makuta and O’Hare (2015) documented a negative association between the five government quality indicators and under-five mortality, and a positive association with life expectancy.

While the above studies already provided valuable insights, at least two major shortcomings can be observed. First, the dependent variable in van Tuyckom’s (2011) was the leisure-time physical activity rate per country, which does not give information about whether the activity level is associated with health benefits. The studies investigating health 
parameters did not state how government quality and population health are connected (Makuta \& O’Hare, 2015; Rabin et al., 2006); for example, other mechanisms apart from sport and physical activity are possible (e.g., nutrition and diet). Thus, it is not clear if those health outcomes were obtained through participation in sport and physical activity.

Second, previous analyses examining the effect of government quality were conducted at the country level (Makuta \& O’Hare, 2015; Rabin et al., 2006; van Tuyckom, 2011), thus neglecting the role of individual factors in explaining sport and physical activity. This has theoretical and statistical ramifications. Theoretically, previous research (Bauman et al., 2012; Bronfenbrenner, 1979; Derom \& VanWynsberghe, 2015) argues that understanding sport and physical activity behaviour requires a socio-ecological approach in which levels of influence are investigated. These levels include, for example, organisational, community, and society (national) levels (Derom \& VanWynsberghe, 2015). Statistically, treating individual-level data (like data on individual sport and physical activity behaviour) as aggregate data is problematic and leads to an atomistic fallacy (Hox, 2002). Ignoring the within-group (i.e., within country) variation can lead to biased estimates (Todd, Crook, \& Barilla, 2005). This study attempts to address these shortcomings by exploring individual-level and country-level data in an analysis of how government quality might provide a more conducive framework and attitude to behaviour that can enhance sport and physical activity and hence health.

\section{Method}

\section{Data sources and samples}

Two datasets are used for examining the relationship between government quality and individual sport and physical activity; the first includes measures of government quality at the country level, together with government expenditure and GDP, and the second includes variables measuring individual characteristics and behaviour. Both datasets are combined within the statistical analysis. The country-level data stem from a dataset which was published 
by the Quality of Government (QOG) Institute and cover countries that are members of the Organisation for Economic Co-operation and Development (OECD) (QOG, 2016; Teorell et al., 2016).

The individual-level data stem from the Eurobarometer, a comprehensive and regular survey of citizens of the 28 member states of the European Union which is authorised by the European Commission. The wave used for this study is the Eurobarometer 80.2 because it contains a set of questions about sport and physical activity (European Commission, 2014). The dataset was obtained from the website of the GESIS Institute (GESIS, 2014). The data were collected in November and December 2013 by TNS Emnid using a multi-stage, random (probability) sampling to ensure that the samples for each country are representative. The country-specific samples comprise approximately 1,000 respondents for large countries, while approximately 500 people are surveyed in small countries (e.g., Luxembourg). A total of 27,919 observations are included in the initial dataset.

The following 21 countries can be used for the analysis because they are included in both the QOG OECD data and the Eurobarometer data: Belgium, Denmark, Greece, Spain, Finland, France, Ireland, Italy, Luxembourg, The Netherlands, Austria, Portugal, Sweden, Germany, UK, Czech Republic, Estonia, Hungary, Poland, Slovakia, and Slovenia. The number of observations in the Eurobarometer data was reduced accordingly to reflect these countries $(n=21,844)$. Moreover, 1,097 observations had to be removed because of missing values on core variables. ${ }^{1}$ Finally, because the WHO (2010) guidelines that we investigate are related to adults aged 18 years and older, and despite the fact that the WHO (2010) also provides recommendations for people between 5 and 17 years, the younger age group is not adequately represented in the Eurobarometer since the youngest interviewees are 15 years old.

\footnotetext{
${ }^{1}$ They are: 499 missing values for physical activity, 357 missing values for difficulty paying bills, and 241 missing values for relationship.
} 
Thus, 328 observations of 15- to 17-year-olds were excluded. Altogether, the final sample consists of $n=20,419$ individuals over 18 years of age, who live in the above 21 countries.

\section{Measures and variables}

An overview of the variables used in this study is provided in Table 1. The sport and physical activity measures were computed based on a set of variables included in the Eurobarometer data (see GESIS, 2013 for details of the questionnaire). Our sport and physical activity variables reflect the WHO (2010) recommendations for adults. Importantly, although the WHO distinguishes between adults aged18 to 64 years and adults aged 65 years and older, the recommendations regarding the amount of moderate- and vigorous-intensity activity which should be performed for health benefits are similar for adults of both age groups.

The first sentence relevant to our study reads as follows: “Adults [...] should do at least 150 minutes of moderate-intensity aerobic physical activity throughout the week, or do at least 75 minutes of vigorous-intensity aerobic physical activity throughout the week, or an equivalent combination of moderate- and vigorous-intensity activity” (WHO, 2010, p. 8). In the survey, respondents were asked to state the number of days in the week prior to the interview they walked for at least ten minutes at a time, practised at moderate intensity (e.g., carrying light loads, cycling at normal pace, doubles tennis; walking was explicitly excluded), and practised at vigorous intensity (e.g., lifting heavy things, digging, aerobics, fast cycling). The examples for both intensities were provided in the questionnaire. Respondents were also asked to state how much time in total they usually spent when they did walk or practised at moderate or vigorous activity (in minutes).

The question is whether walking should be included in sport and physical activity measures or not. On the one hand it was assessed separately from moderate and vigorous activity in the Eurobarometer survey, indicating that it should not be included. On the other hand, previous research included light-intensity activity such as walking in their sport and 
physical activity measure (e.g., Downward \& Rasciute, 2010; Humphreys \& Ruseski, 2007, 2015; Wicker et al., 2009). Moreover, the official guidelines by the U.S. Department of Health and Human Services et al. (1999) suggest that walking qualifies as moderate-intensity activity when it is conducted at a moderate or brisk pace of 3 to 4.5 miles per hour. This includes, for example, walking to class, work, or the store; walking for pleasure; walking the dog; or walking as a break from work. In the same guidelines, walking is even considered vigorous activity when the pace is 5 miles per hour or faster, like in race-walking and aerobic walking. However, as neither walking pace nor purpose was assessed in the Eurobarometer survey, we decided to compute two groups of sport and physical activity measures; the first include walking (denoted Sport_walk_) and the second exclude walking (denoted Sport_). Based on the information in the survey, the first two measures were computed for both groups: Sport_walk_below and Sport_below are equal to 1 when individuals are physically active, but do not meet the threshold of the WHO (2010); Sport_walk_meet and Sport_meet are equal to 1 when an individual's level of sport and physical activity meets the threshold recommended by the WHO (2010).

The next relevant sentence of the recommendations states the following: "For additional health benefits, adults should increase their moderate-intensity aerobic physical activity to 300 minutes per week, or engage in 150 minutes of vigorous-intensity aerobic physical activity per week, or an equivalent combination of moderate- and vigorous-intensity activity” (WHO, 2010, p. 8). The variables Sport_walk_exceed and Sport_exceed are equal to 1 when the individual meets this recommendation for additional health benefits. ${ }^{2}$ Hence, our sport and physical activity measures already include expected health outcomes.

Having said this, the sport and physical activity measures applied in this study differ from those used by Lera-Lopez et al. (2016). Specifically, information about participation

\footnotetext{
${ }^{2}$ Note that the sport and physical activity measures are mutually exclusive. For example, individuals reporting an activity level which exceeds the guidelines score 0 on Sport_walk_meet and Sport_meet, respectively.
} 
intensity and duration is needed to calculate the present measures; this information was not available in the 2009 wave of the Eurobarometer used by Lera-Lopez et al. (2016). Thus, they were only able to distinguish between different participation frequencies of sport and physical activity. While the latter also allow statements about potential health effects, an analysis of the concrete WHO (2010) recommendations as conducted in this study was not possible.

As documented in the literature (e.g., Downward et al., 2014; Downward \& Rasciute, 2010; Humphreys \& Ruseski, 2015; Lera-Lopez et al., 2016; Wicker et al., 2013), an individual's level of sport and physical activity can be affected by various individual factors including age, gender, occupation, marital status, children, and the financial situation. Therefore, the present study controls for these factors (see Table 1 for measurement details).

Turning to country-level variables, government quality is measured with the following six worldwide governance indicators (Worldbank, 2016): control of corruption, government effectiveness, political stability and absence of violence/terrorism, rule of law, voice and accountability, and regulatory quality. The six indicators have been developed based on several hundreds of variables measuring perceptions of governance which were drawn from more than 30 data sources including survey respondents as well as public, private, and nongovernmental sector experts worldwide. They are normally distributed and have a range from -2.5 to +2.5 (Kaufmann et al., 2010; Teorell et al., 2016). While the comparison of government quality across countries has been challenged, Kaufmann et al. (2010) concluded that these indicators allow meaningful cross-country and over-time comparisons. They can be considered appropriate measures of government quality which have been applied in previous research - both separately (Makuta \& O’Hare, 2015) and using an additive equally weighted index in addition to the six indicators (Rabin et al., 2006; van Tuyckom, 2011). This study also uses an overall (additive) index (Govtqual; Table 1). The separate indicators were not 
used in the empirical analysis since there is no strong theoretical rationale that they affect sport and physical activity in different ways.

Since democratic values, and hence government quality, have been shown to affect a country’s economic growth (Glaeser, La Porta, Lopez-de-Silanes, \& Shleifer, 2004), and because equally for a democracy to function some level of economic development is required as a platform on which to raise government quality (Charron \& Lapuente, 2010), our analysis takes GDP into account. To allow cross-country and over-time comparisons, we include GDP per capita in purchasing power parities (PPP) and in 2011 US dollars (GDP_pc). Furthermore, since previous research found a significant effect of health and education spending on participation in sport and physical activity (Lera-Lopez et al., 2016), these two measures are also included in the study.

However, GDP and government quality are highly correlated, as expected from the literature (e.g., Glaeser et al., 2004). Also, government spending on health (Health_exp) and education (Edu_exp) are correlated with government quality. Consequently, it is not possible to include GDP and the two government spending variables as additional control variables in the same analysis. To be nevertheless able to control for GDP and government spending in our analysis, we calculated a government quality variable that is purged of GDP and government spending. Specifically, we obtained the residuals (Govtqual_res) when regressing government quality on GDP, health spending, and education spending (Table 1).

Another point of discussion is the data collection period. Since the Eurobarometer data were collected in winter (November and December) and the participation questions asked for activity in the week prior to the interview, responses may be affected by season. Previous research showed mixed findings regarding the role of season in individual physical activity patterns: while some studies found no significant effect of survey month on individual physical activity patterns (e.g., Gordon-Larsen, McMurray, \& Popkin, 2000), others 
documented that variations across seasons exist for both specific activity types such as moderate-intensity physical activity (e.g., Hagströmer, Rizzo, \& Sjöström, 2014) and overall physical activity level (e.g., Matthews et al., 2001). The survey period should be kept in mind when interpreting the results of this study.

\section{Insert Table 1 here}

\section{Empirical analysis}

The empirical analysis takes the socio-ecological structure into account, implying that influences on individual participation in sport and physical activity arise from the more aggregate context and environment. In analysing government quality as the latter, the hierarchical data structure must be considered: individuals are nested within countries meaning that the characteristics of one country apply to all individuals living in this country. Some studies have treated the country-level variables as individual data (Downward et al., 2014; Ruseski \& Maresova, 2014); yet, this can be problematic for several reasons. First, the assumption of independent observations which is required for conventional regression analysis is violated (Peugh, 2010). Second, an artificial increase in the degrees of freedom results in biased standard errors which lead to an inflation of the Type I error. To an extent these statistical inefficiencies can be controlled for by clustered standard errors. However, and fundamentally, third, there is the potential of an ecological fallacy meaning that higher-level results are misleadingly ascribed to the lower level in the case of having direct concern with the scale and influence of the higher-level variables (Tabachnick \& Fidell, 2007).

For these reasons, multi-level analysis should be applied because this research focuses on the influence of higher-level effects (Bryk \& Raudenbush, 1992). Multi-level models have already been applied in previous policy and sport participation research where individual behaviour was explained with individual-level and country-level data (Angel \& Heitzmann, 2015; Lera-Lopez et al., 2016). They require a large number of observations at the lower level 
and at least 20 cases at the higher level (Snijders \& Bosker, 1999) - both criteria are met by this study. The multi-level models were estimated using the software HLM 7.1 (Raudenbush, Bryk, Cheong, Congdon, \& Du Toit, 2011).

Altogether, four sets of multi-level models were estimated; two sets for the dependent variables measuring sport and physical activity including walking and another two sets for the measures excluding walking. The first and second sets of models are run with the measures including walking (i.e., Sport_walk_below, Sport_walk_meet, Sport_walk_exceed). In the first set, the government quality index (govtqual) was entered at the country level. In the second set, government quality residuals, GDP, and government spending (Health_exp, Edu_exp) were included as independent country-level variables. The latter three variables control for other factors potentially affecting individual participation in sport and physical activity and test the robustness of the first set of models. The third and fourth sets of models were estimated using the sport and physical activity measures excluding walking (i.e., Sport_below, Sport_meet, Sport_exceed). The modelling strategy was the same as for the first two sets of models; the third set of models included the government quality index, while government quality residuals, GDP, and the two government spending variables were entered in the fourth set. All models include the same set of individual-level variables (Table 1) and were estimated with robust standard errors to control for any further heteroscedasticity in the data.

\section{Results and discussion}

The summary statistics are reported in Table 2. The individual-level statistics show that $44.9 \%$ of respondents are male. The average age is 51 years. Almost two thirds of respondents are in a relationship. Altogether, 18.5\% have children younger than ten years and 10.9\% have children between 10 and 14 years in their household. The majority of respondents (almost) never have difficulties paying bills. 
Regarding sport and physical activity measures including walking, 15.2\% of respondents are physically active, but the activity level is below the WHO (2010) guidelines, while $11.2 \%$ have an activity level which meets the guidelines. The activity level of $48.9 \%$ of respondents exceeds the guidelines. When walking is excluded, the latter percentage drops to $33.2 \%$. While both figures may seem relatively high, they are mirrored in data from the Active People Survey from the same year (Sport England, 2013). In the UK, the share of people reporting participation in sport at least once a week was approximately $36 \%$, while the share of respondents participating in any sport was approximately $48 \%$ - both measures exclude walking. In this study, when walking is excluded, the activity level of $11.6 \%$ of respondents meets the WHO (2010) guidelines, while the share of respondents reporting an activity level below the guidelines increases to $18.5 \%$.

Insert Table 2 here

Turning to country-level variables, the average government quality index is 1.19 on a scale from -2.5 to +2.5 . Table 3 reports this index for each country. It can be seen that the Scandinavian countries Finland, Denmark, and Sweden are characterised by the highest levels of government quality, followed by Luxembourg and The Netherlands. Government quality was found to be lowest in Hungary, Italy, and Greece. Concerning the controls (Table 2), average per capita GDP is $\$ 36,906$ in the investigated countries. On average, these countries spent a higher share of their national GDP on health than on education.

Insert Table 3 here

The results of the multi-level analyses for sport and physical activity are summarised in Tables 4 (including walking) and 5 (excluding walking). The individual-level variables serve as controls in an effort to isolate the effect of government quality and other countrylevel variables. Since their relationship with sport and physical activity is similar to previous research, for example males are more likely to report higher activity levels than females (e.g., 
Downward et al., 2014), young children (e.g., Ruseski et al., 2011) and financial difficulties constrain physical activity (e.g., Lera-Lopez et al., 2016), the findings regarding the countrylevel variables including government quality variables can be considered credible.

In the first set of models analysing sport and physical activity including walking (Table 4), government quality is insignificant in model 1.1 examining individuals with an activity level that falls below the WHO (2010) guidelines. In contrast, however, positive and statistically significant effects are identified for Sport_walk_meet and Sport_walk_exceed; that means where individuals meet or exceed the WHO guidelines. The second set of models shows similar results: when controlling for GDP and government spending, the effect of the residuals of government quality is insignificant for sport and physical activity below the guidelines, but positive and significant for activity levels meeting and exceeding the guidelines. This means that government quality cleaned by the effect of GDP and government spending still has a significant positive impact. The odds ratios in the first set of models range from 1.10 to 2.36 approximately, whereas they range from 1.06 to 3.09 in the second set of models. This means that the odds of increased participation in sport and physical activity are enhanced in the presence of greater government quality, and more so for higher levels of physical activity.

Turning to the models examining sport and physical activity excluding walking (Table 5), government quality has a statistically significant and positive effect in the third set of models. Thus, when walking is excluded from the dependent variable, the effect of government quality on participation in sport and physical activity below the guidelines turns significant. The fourth set of models shows a similar pattern to the second set of models; when controlling for GDP and government spending, the residuals of government quality are insignificant in the model for an activity level below the guidelines, but have a positive and significant impact on participation in sport and physical at a level meeting and exceeding the 
guidelines. Similar to the first two sets of models, the odds ratios increase as we move from activity below the guidelines to activity exceeding the guidelines.

The national-level control variables are insignificant in all models with the exception of per capita GDP which has a significant positive effect in four out of six models. The insignificance of education and health spending is contrary to previous research documenting significant positive effects (Lera-Lopez et al., 2016). However, the present study is slightly different from Lera-Lopez et al. (2016) in the sense that the participation measures considered not only frequency, but also duration and intensity of the activity, and fewer countries were included in the analysis. When estimating the models with government quality and the residuals of health and education spending cleaned by government quality and per capita GDP, the effect of government quality is still positive and significant in all six models with the exception of Sport_walk_below (results available upon request). The residuals of the spending variables are insignificant, suggesting that the findings by Lera-Lopez et al. (2016) are also partially driven by government quality, although it is difficult to isolate causal chains.

Altogether, the results yield strong evidence that government quality has a positive effect on sport and physical activity of individuals. The present findings support the earlier arguments that government quality can enhance participation in sport and physical activity through regulatory frameworks and also the opportunities to engage in society particularly. They also support the view that it is government quality per se that is contributing to the differences in individual participation in sport and physical activity. This finding is in line with van Tuyckom (2011), but contrary to her study our research documents the effect of government quality on individual behaviour instead of nationwide participation rates. Moreover, our measures include the respective health outcomes expected from an individual's sport and physical activity level. 


\section{Conclusion and implications}

This study examined the relationship between government quality and individual health production through participation in sport and physical activity using data from 21 European countries. Sport and physical activity is analysed with respect to an individual's activity level being below, meeting, or exceeding the physical activity guidelines of the WHO (2010). The results of multi-level models show that overall government quality (i.e., an additive index of six constituent dimensions) has a significant positive effect on the likelihood of individual participation in sport and physical activity (including and excluding walking), with the largest effect being identified as we consider moves to exceeding the guidelines. To control for the potential impact of GDP and government spending on health and education, an additional analysis was undertaken. This involved using the residuals from a regression of government quality on GDP and government spending on health and education, which yields a measure of government quality that is cleaned of the effect of the latter variables. It is shown that government quality still has a positive association with individual participation in sport and physical activity.

The implications of these results do not easily transfer to particular organisational behaviours or specific managerial implications. However, they are important and relevant for sport management at the macro-policy level, and particularly in the pan-European dimension in which supranational and supranational-informed national policy takes place. The implications of the research above are that, for example, in seeking to meet the needs of the European Sports Charter, national and EU government integrity is important. Responsibility does not simply lie with sport organisations. In this regard governments are not neutral institutional arrangements that deliver on policy outcomes through their actions on others, including pressing laudable arguments in the public policy environment that more sport and physical activity is needed and that the governance and integrity of organisations that 
specifically deliver physical activity opportunities needs review. The current research shows that a more open and accountable government per se can provide the regulatory framework and tolerance required for more effective structural delivery of physical activity in society as well as the environment in which behaviours can change.

There are of course, limitations to the analysis, notably the use of cross-sectional data which limits the ability of the research to explore the likely dynamics of changed behaviour more effectively. Another limitation is the survey period of the Eurobarometer 80.2 dataset which was in the winter and may have affected the responses to the sport and physical activity questions - physical activity patterns may be different in the winter season and also dependent on the provision of covered facilities and winter sport opportunities in a country. Nonetheless, the research does indicate a fruitful line of future enquiry unpicking further the mechanisms by which government quality affects individual behaviour and also to explore how threats to open society, for example in the light of terrorist or refugee crises, could have negative health consequences in the clamour to tighten up and restrict access to opportunities in society.

\section{References}

Angel, S., \& Heitzmann, K. (2015). Over-indebtedness in Europe: The relevance of countrylevel variables for the over-indebtedness of private households. Journal of European Social Policy, 25(3), 331-351.

Bauman, A. E., Reis, R. S., Sallis, J. F., Wells, J. C., Loos, R. J., \& Martin, B. W. (2012). Correlates of physical activity: Why are some people physically active and others not? The Lancet, 380(9838), 258-271.

Bean, B. W. (2016). An interim essay on FIFA's World Cup of corruption: The desperate need for international corporate governance standards at FIFA. ILSA Journal of International \& Comparative Law, 22(2), 1-27. 
Berens, S. (2015). Between exclusion and calculating solidarity? Preferences for private versus public welfare provision and the size of the informal sector. Socio-Economic Review, 13(4), 651-678.

Blair, S. (2009). Physical activity: the biggest public health problem of the $21^{\text {st }}$ century. British Journal of Sports Medicine, 43, 1-2.

Bronfenbrenner, U. (1979). The ecology of human development: Experiments by nature and design. Cambridge, MA: Harvard University Press.

Bryk, A. S., \& Raudenbush, S. W. (1992). Hierarchical linear models. Newbury Park, CA: Sage Publications.

Charron, N., \& Lapuente, V. (2010). Does democracy produce quality of government? European. Journal of Political Research, 49(4), 443-470.

DCMS. (2002). Game Plan: A strategy for delivering government's sport and physical activity objectives. London: Cabinet Office.

Derom, I., \& VanWynsberghe, R. (2015). Extending the benefits of leveraging cycling events: evidence from the Tour of Flanders. European Sport Management Quarterly, 15(1), 111-131.

Downward, P., \& Rasciute, S. (2010). The relative demands for sports and leisure in England. European Sport Management Quarterly, 10(2), 189-214.

Downward, P., \& Rasciute, S. (2015). Exploring the covariates of sport participation for health: an analysis of males and females in England. Journal of Sports Sciences, 33(1), $67-76$.

Downward, P., Dawson, A., \& Dejonghe, T. (2009). Sport economics. Theory, evidence and policy. Oxford: Butterworth-Heinemann. 
Downward, P., Dawson, P., \& Mills, T. C. (2015). Sports participation as an investment in (subjective) health: A time series analysis of the life course. Journal of Public Health (in press). doi:10.1093/pubmed/fdv164.

Downward, P., Lera-Lopez, F., \& Rasciute, S. (2014). The correlates of sports participation in Europe. European Journal of Sport Science, 14(6), 37-41.

European Commission. (2014). Eurobarometer 80.2 (2013). TNS Opinion [producer]. 2014:

GESIS Data Archive, Cologne. ZA5877 data file Version 1.0.0. 2014. doi: 10.4232/1.12010.

European Commission. (2016). Organisation of sport. Retrieved May 04, 2016 from http://ec.europa.eu/sport/policy/organisation_of_sport/index_en.htm

Frick, B., \& Wicker, P. (2016). The trickle-down effect: how elite sporting success affects amateur participation in German football. Applied Economics Letters, 23(4), 259-263.

GESIS. (2013). Eurobarometer 80.2. November-December 2013. Basic bilingual questionnaire. Retrieved March 6, 2015 from http://www.gesis.org/?id=8920\&tx_eurobaromater_pi1[vol]=8920\&tx_eurobaromater _pi1[pos1] $=0$

GESIS. (2014). ZA5877: Eurobarometer 80.2 (2013). Retrieved January 16, 2014 from https://dbk.gesis.org/dbksearch/SDESC2.asp?no=5877\&amp;amp;search=Eurobarome ter\&amp;amp;search2=\&amp;amp;DB=E

Glaeser, E. L, La Porta, R., Lopez-de-Silanes, F., \& Shleifer, A. (2004). Do institutions cause growth? Journal of Economic Growth, 9(3), 271-303.

Gordon-Larsen, P., McMurray, R. G., \& Popkin, B. M. (2000). Determinants of physical activity and inactivity patterns. Pediatrics, 105(6), 1-8.

Grix, J., \& Carmichael, F. (2012). Why do governments invest in elite sport? A polemic. International Journal of Sport Policy and Politics, 4(1), 73-90. 
Hagströmer, M., Rizzo, N. S., \& Sjöström, M. (2014). Associations of season and region on objectively assessed physical activity and sedentary behaviour. Journal of Sports Sciences, 32(7), 629-634.

HM Government. (2015). Sporting future: A new strategy for an active nation. Retrieved April 15, 2016 from https://www.gov.uk/government/uploads/system/uploads/attachment_data/file/486622/ Sporting_Future_ACCESSIBLE.pdf.

Hodgkinson, I. R., Hughes, P., \& Hughes, M. (2012). Re-examining the deployment of market orientation in the public leisure sector. Journal of Marketing Management, 28(11-12), 1249-1269.

Houlihan, B. \& Lindsay, I. (2012). Sport policy in Britain. London: Routledge.

Hox, J. J. (2002). Multilevel analysis. Mahwah, NJ: Lawrence Erlbaum Associates.

Humpel, N., Owen, N., \& Leslie, E. (2002). Environmental factors associated with adults’ participation in physical activity: a review. American Journal of Preventive Medicine, 22(3), 188-199.

Humphreys, B. R., \& Ruseski, J. E. (2007). Participation in physical activity and government spending on parks and recreation. Contemporary Economic Policy, 25(4), 538-552.

Humphreys, B. R., \& Ruseski, J. E. (2015). The economic choice of participation and time spent in physical activity and sport in Canada. International Journal of Sport Finance, 10(2), 138-159.

Humphreys, B. R., McLeod, L., \& Ruseski, J. E. (2014). Physical activity and health outcomes: evidence from Canada. Health Economics, 23(1), 33-54.

Kaufmann, D., Kraay, A., \& Mastruzzi, M. (2010). The worldwide governance indicators. Methodology and analytical issues. Policy Research Working Paper No. 5430. 
Retrieved February 19, 2016 from

http://papers.ssrn.com/sol3/papers.cfm?abstract_id=1682130

Kenchaiah, S., Evans, J. C., Levy, D., Wilson, P. W., Benjamin, E. J., Larson, M. G., ... Vasan, R. S. (2002). Obesity and the risk of heart failure. New England Journal of Medicine, 347(5), 305-313.

Kokolakakis, T., Lera-Lopez, F., \& Castellanos, P. (2014). Regional differences in sports participation: The case of local authorities in England. International Journal of Sport Finance, 9(2), 149-171.

Kurzer, P., \& Cooper, A. (2011). Hold the croissant! The European Union declares war on obesity. Journal of European Social Policy, 25(3), 331-351.

Lang, T., \& Tayner, G. (2005). Obesity: a growing issue for European policy? Journal of European Social Policy, 15(4), 301-327.

Larsson, S. C., \& Wolk, A. (2007). Overweight, obesity and risk of liver cancer: a metaanalysis of cohort studies. British Journal of Cancer, 97(7), 1005-1008.

Lera-Lopez, F., Wicker, P., \& Downward, P. (2016). Does government spending help to promote healthy behavior in the population? Evidence from 27 European countries. Journal of Public Health, 38(2), e5-e12.

Liu, B., Balkwill, A., Banks, E., Cooper, C., Green, J., \& Beral, V. (2007). Relationship of height, weight and body mass index to the risk of hip and knee replacements in middle-aged women. Rheumatology, 46(5), 861-867.

Makuta, I., \& O’Hare, B. (2015). Quality of governance, public spending on health and health status in Sub Saharan Africa: a panel data regression analysis. BMC Public Health, 15(932), 1-11. 
Mather, V., \& Clarey, C. (2015). Russia suspended from World track and field. Retrieved May 04, 2016 from http://www.nytimes.com/2015/11/14/sports/russia-suspended-bytrack-and-fields-governing-body.html?_r=1

Matthews, C. E., Freedson, P. S., Hebert, J. R., Stanek III, E. L., Marriam, P. A., Rosal, M. C., et al. (2001). Seasonal variation in household, occupational, and leisure time physical activity: longitudinal analyses from the seasonal variation of blood cholesterol study. American Journal of Epidemiology, 153(2), 172-183.

Mullahy, J., \& Robert, S. A. (2010). No time to lose: time constraints and physical activity in the production of health. Review of Economics of the Household, 8(4), 409-432.

New York Times. (2015). In FIFA Inquiry, Switzerland Aids U.S. but Is Wary of Being Eclipsed. Retrieved May 25, 2016 from http://www.nytimes.com/2015/12/06/sports/soccer/in-fifa-inquiry-switzerland-aids-usbut-is-wary-of-being-eclipsed.html?_r=0

Norman, G. J., Nutter, S. K., Ryan, S., Sallis, J. F., Calfas, K. J., \& Patrick, K. (2006). Community design and access to recreational facilities as correlates of adolescent physical activity and body-mass index. Journal of Physical Activity and Health, 3(1), 118-28.

Peugh, J. L. (2010). A practical guide to multilevel modeling. Journal of School Psychology, 48, 85-112.

QOG. (2016). QoG OECD Data. Retrieved February 19, 2016 from http://qog.pol.gu.se/data/datadownloads/qogoecddata

Rabin, B.A., Boehmer, T.K. \& Brownson, R.C. (2006). Cross-national comparison of environmental and policy correlates of obesity in Europe. European Journal of Public Health, 17(1), 53-61. 
Raudenbush, S., Bryk, A., Cheong, Y.-F., Congdon, R., \& Du Toit, M. (2011). HLM 7. Lincolnwood: Scientific Software International Inc.

Roy, I. (2005). Good governance and the dilemma of development: what lies beneath? SocioEconomic Review, 3(1), 83-116.

Ruseski, J. E., \& Maresova, K. (2014). Economic freedom, sport policy, and individual participation in physical activity: an international comparison. Contemporary Economics Policy, 32(1), 42-55.

Ruseski, J. E., Humphreys, B. R., Hallmann, K., \& Breuer, C. (2011). Family structure, time constraints, and sport participation. European Review of Aging \& Physical Activity, 8(2), 57-66.

Snijders, T. A., \& Bosker, R. J. (1999). Multilevel analysis - An introduction to basic and advanced multilevel modeling. London: Sage.

Sport England. (2013). Active People Interactive. Retrieved July 13, 2016 from http://activepeople.sportengland.org/Query

Sydney Morning Herald. (2015). British government could back World Cup boycott to oust Blatter from FIFA. Retrieved May 25, 2016 from http://www.smh.com.au/sport/soccer/british-government-could-back-world-cupboycott-to-oust-blatter-from-fifa-20150531-ghdpbf.html\#ixzz49g55T0cX

Tabachnick, B. G., \& Fidell, L. S. (2007). Using multivariate statistics. Boston, MA: Allyn \& Bacon.

Teorell, J., Kumlin, S., Dahlberg, S., Holmberg, S., Rothstein, B., Hartmann, F., \& Svensson, R. (2016). The Quality of Government OECD Dataset, version Jan16. University of Gothenburg: The Quality of Government Institute.

TNS BMRB. (2012). Inspiring a generation: A taking part report on the 2012 Olympic and Paralympic Games. Retrieved May 04, 2016 from 
https://www.gov.uk/government/uploads/system/uploads/attachment_data/file/78316/ Taking_Part_Olympic_Report.pdf

Todd, S. Y., Crook, T. R., \& Barilla, A. G. (2005). Hierarchical linear modeling of multilevel data. Journal of Sport Management, 19(4), 387-403.

United Nations. (2016). Sport for development and peace. Retrieved May 04, 2016 from http://www.un.org/wcm/content/site/sport/home/sport

U.S. Department of Health and Human Services, Public Health Service, Centers for Disease Control and Prevention, National Center for Chronic Disease Prevention and Health Promotion, \& Division of Nutrition and Physical Activity. (1999). Promoting physical activity: a guide for community action. Champaign, IL: Human Kinetics.

Van Tuyckom, C. (2011). Macro-environmental factors associated with leisure-time physical activity: A cross-national analysis of EU countries. Scandinavian Journal of Public Health, 39, 419-426.

Weed, M., Coren, E., Fiore, J., Wellard, I., Chatziefstathiou, D., Mansfield, L., \& Dowse, S. (2015). The Olympic Games and raising sport participation: a systematic review of evidence and an interrogation of policy for a demonstration effect. European Sport Management Quarterly, 15(2), 195-226.

Weisbrod, B. A. (1978). The voluntary nonprofit sector. Lexington: Lexington books.

Warburton, D. E. R., Nicol, C. W., \& Bredin, S. S. D. (2006). Health benefits of physical activity: the evidence. Canadian Medical Association Journal, 174(6), 801-809.

Weimar, D., Wicker, P., \& Prinz, J. (2015). Membership in nonprofit sport club: A dynamic panel analysis of external organizational factors. Nonprofit and Voluntary Sector Quarterly, 44(3), 417-436.

WHO. (2000). Obesity: Preventing and managing the global epidemic. Retrieved February 20, 2016 from http://www.who.int/nutrition/publications/obesity/WHO_TRS_894/en/ 
WHO. (2010). Global recommendations on physical activity for health. Retrieved January 16, 2015 from http://whqlibdoc.who.int/publications/2010/9789241599979_eng.pdf?ua=1

Wicker, P., Breuer, C., \& Pawlowski, T. (2009). Promoting sport for all to age-specific target groups: the impact of sport infrastructure. European Sport Management Quarterly, 9(2), 103-118.

Wicker, P., Hallmann, K., \& Breuer, C. (2013). Analyzing the impact of sport infrastructure on sport participation using geo-coded data: Evidence from multi-level models. Sport Management Review, 16(1), 54-67.

Worldbank. (2016). Worldwide governance indicators. Retrieved February 19, 2016 from http://info.worldbank.org/governance/wgi/index.aspx\#home 
Table 1

Overview of variables

\begin{tabular}{|c|c|}
\hline Variable & Description \\
\hline \multicolumn{2}{|l|}{ Dependent variables } \\
\hline Sport_walk_below & $\begin{array}{l}\text { Sport and physical activity level including walking is below the } \\
\text { WHO guidelines (1=yes) }\end{array}$ \\
\hline Sport_walk_meet & $\begin{array}{l}\text { Sport and physical activity level including walking meets the WHO } \\
\text { guidelines, but no additional health benefits (1=yes) }\end{array}$ \\
\hline Sport_walk_exceed & $\begin{array}{l}\text { Sport and physical activity level including walking exceeds the WHO } \\
\text { guidelines and produces additional health benefits ( } 1=\text { yes) }\end{array}$ \\
\hline Sport_below & $\begin{array}{l}\text { Sport and physical activity level excluding walking is below the } \\
\text { WHO guidelines (1=yes) }\end{array}$ \\
\hline Sport_meet & $\begin{array}{l}\text { Sport and physical activity level excluding walking meets the WHO } \\
\text { guidelines, but no additional health benefits ( } 1=\text { yes) }\end{array}$ \\
\hline Sport_exceed & $\begin{array}{l}\text { Sport and physical activity level excluding walking exceeds the } \\
\text { WHO guidelines and produces additional health benefits ( } 1=\text { yes) }\end{array}$ \\
\hline \multicolumn{2}{|c|}{ Country-level variables } \\
\hline Govtqual & $\begin{array}{l}\text { Additive government quality index of six indicators (i.e., voice and } \\
\text { accountability, political stability and absence of violence, government } \\
\text { effectiveness, regulatory quality, rule of law, and control of } \\
\text { corruption; equal weights; 2009-2013 mean) }\end{array}$ \\
\hline \multirow[t]{2}{*}{ Govtqual_res } & Residuals of the following equation: \\
\hline & Govtqual $=\beta_{0}+\beta_{1}$ GDP $+\beta_{2}$ Health_exp $+\beta_{3}$ Edu_exp $+\varepsilon$ \\
\hline GDP_pc & GDP per capita (in PPP and 2011 US dollars; 2009-2013 mean) \\
\hline Health_exp & $\begin{array}{l}\text { Government spending on health (percent of national GDP; 2009-2013 } \\
\text { mean) }\end{array}$ \\
\hline Edu_exp & $\begin{array}{l}\text { Government spending on education (percent of national GDP; 2009- } \\
2013 \text { mean) }\end{array}$ \\
\hline \multicolumn{2}{|c|}{ Individual-level variables } \\
\hline Male & Gender of respondent (1=male) \\
\hline Age & Age of respondent \\
\hline Age_sq & Age squared (=Age*Age) \\
\hline Relationship & Respondent is in a relationship (1=yes) \\
\hline Kids_u10 & Children under 10 years in household (1=yes) \\
\hline Kids_1014 & Children between 10 and 14 years in household (1=yes) \\
\hline Self-employed & $\begin{array}{l}\text { Self-employed (1=yes); including farmer, fisherman, professional, } \\
\text { owner of a shop, craftsmen, business proprietor }\end{array}$ \\
\hline Employed & $\begin{array}{l}\text { Employed (1=yes); including employed professional, general or } \\
\text { middle management, employed position (at desk, travelling, service } \\
\text { job), supervisor, (un)skilled manual worker }\end{array}$ \\
\hline Not_working & $\begin{array}{l}\text { Not working (1=yes); including responsible for ordinary shopping, } \\
\text { student, unemployed, temporarily not working, retired, unable to } \\
\text { work }\end{array}$ \\
\hline Diffpay_mostly & Difficulty paying bills (1=most of the time) \\
\hline Diffpay_sometimes & Difficulty paying bills (1=from time to time) \\
\hline Diffpay_never & Difficulty paying bills ( $1=$ never/almost never) \\
\hline
\end{tabular}


Table 2

Summary statistics

\begin{tabular}{|c|c|c|c|c|c|}
\hline Variable & $\mathrm{n}$ & Mean & SD & Min & Max \\
\hline \multicolumn{6}{|l|}{ Dependent variables } \\
\hline Sport_walk_below & 20,419 & 0.152 & --- & 0 & 1 \\
\hline Sport_walk_meet & 20,419 & 0.112 & --- & 0 & 1 \\
\hline Sport_walk_exceed & 20,419 & 0.489 & --- & 0 & 1 \\
\hline Sport_below & 20,419 & 0.185 & --- & 0 & 1 \\
\hline Sport_meet & 20,419 & 0.116 & --- & 0 & 1 \\
\hline Sport_exceed & 20,419 & 0.332 & --- & 0 & 1 \\
\hline \multicolumn{6}{|l|}{ Country-level variables } \\
\hline Govtqual & 21 & 1.19 & 0.46 & 0.35 & 1.86 \\
\hline Govtqual_res & 21 & 0.00 & 0.26 & -0.44 & 0.39 \\
\hline GDP_pc & 21 & $36,905.61$ & $14,489.57$ & $22,131.45$ & $775,017.87$ \\
\hline Health_exp & 21 & 6.74 & 1.59 & 1.84 & 8.66 \\
\hline Edu_exp & 21 & 5.50 & 0.94 & 4.12 & 7.02 \\
\hline \multicolumn{6}{|l|}{ Individual-level variables } \\
\hline Male & 20,419 & 0.449 & --- & 0 & 1 \\
\hline Age & 20,419 & 51.07 & 17.42 & 18 & 98 \\
\hline Age_sq & 20,419 & $2,911.19$ & $1,811.15$ & 324 & 9,604 \\
\hline Relationship & 20,419 & 0.647 & --- & 0 & 1 \\
\hline Kids_u10 & 20,419 & 0.185 & --- & 0 & 1 \\
\hline Kids_1014 & 20,419 & 0.109 & --- & 0 & 1 \\
\hline Self-employed & 20,419 & 0.075 & --- & 0 & 1 \\
\hline Employed & 20,419 & 0.422 & --- & 0 & 1 \\
\hline Not_working & 20,419 & 0.503 & --- & 0 & 1 \\
\hline Diffbills_mostly & 20,419 & 0.115 & --- & 0 & 1 \\
\hline Diffbills_sometimes & 20,419 & 0.256 & --- & 0 & 1 \\
\hline Diffbills_never & 20,419 & 0.629 & --- & 0 & 1 \\
\hline
\end{tabular}


Table 3

Government quality index by country (2009-2013 mean)

\begin{tabular}{llll}
\hline \multicolumn{2}{l}{ Sorted alphabetically by country } & \multicolumn{2}{l}{ Sorted by Govtqual in descending order } \\
\hline Country & Govtqual & Country & Govtqual \\
\hline Austria & 1.52 & Finland & 1.86 \\
Belgium & 1.34 & Denmark & 1.81 \\
Czech Republik & 0.89 & Sweden & 1.80 \\
Denmark & 1.81 & Luxembourg & 1.71 \\
Estonia & 1.04 & The Netherlands & 1.68 \\
Finland & 1.86 & Austria & 1.52 \\
France & 1.20 & Germany & 1.44 \\
Germany & 1.44 & Ireland & 1.44 \\
Greece & 0.35 & United Kingdom & 1.36 \\
Hungary & 0.69 & Belgium & 1.34 \\
Ireland & 1.44 & France & 1.20 \\
Italy & 0.51 & Estonia & 1.04 \\
Luxembourg & 1.71 & Portugal & 0.95 \\
Poland & 0.80 & Slovenia & 0.92 \\
Portugal & 0.95 & Czech Republik & 0.89 \\
Slovakia & 0.74 & Spain & 0.85 \\
Slovenia & 0.92 & Poland & 0.80 \\
Spain & 0.85 & Slovakia & 0.74 \\
Sweden & 1.80 & Hungary & 0.69 \\
The Netherlands & 1.68 & Italy & 0.51 \\
United Kingdom & 1.36 & Greece & 0.35 \\
\hline Total & 1.19 & Total & 1.19 \\
\hline & & &
\end{tabular}


Table 4

Results of the multi-level models for sport and physical activity including walking

\begin{tabular}{|c|c|c|c|c|c|c|}
\hline & Model 1.1 & Model 1.2 & Model 1.3 & Model 2.1 & Model 2.2 & Model 2.3 \\
\hline & Sport_walk_below & Sport_walk_meet & Sport_walk_exceed & Sport_walk_below & Sport_walk_meet & Sport_walk_exceed \\
\hline Intercept & $0.124 * * *$ & $0.057 * * *$ & $0.410 * *$ & $0.091^{* * *}$ & $0.056 * * *$ & $0.228 * *$ \\
\hline Govtqual & 1.104 & $1.256^{*}$ & $2.362 * * *$ & --- & --- & --- \\
\hline Govtqual_res & --- & --- & --- & 1.057 & $1.475 *$ & $3.094 * * *$ \\
\hline GDP_pc & --- & --- & --- & 1.000 & 1.000 & $1.000 * *$ \\
\hline Health_exp & --- & --- & --- & 0.980 & 1.006 & 1.010 \\
\hline Edu_exp & --- & --- & --- & 1.102 & 1.026 & 1.101 \\
\hline Male & $0.823 * * *$ & 0.914 & $1.403 * * *$ & $0.824 * * *$ & $0.914 *$ & $1.627 * * *$ \\
\hline Age & 1.002 & 1.014 & 1.003 & 1.003 & 1.015 & 0.995 \\
\hline Age_sq & 0.999 & $0.999 *$ & $0.999 * * *$ & 1.000 & $1.000 *$ & $1.000 * *$ \\
\hline Relationship & 1.033 & $1.086 *$ & $1.078 *$ & 1.034 & 1.087 & $1.146 * * *$ \\
\hline Kids_u10 & 0.983 & 1.008 & $0.880 * *$ & 0.983 & 1.010 & $0.862 * * *$ \\
\hline Kids_1014 & 1.041 & 1.034 & 1.012 & 1.041 & 1.035 & 0.990 \\
\hline Self-employed & $0.829 *$ & 1.076 & $1.161 *$ & $0.830 *$ & 1.077 & $1.444 * * *$ \\
\hline Employed & 0.960 & 1.048 & 1.041 & 0.960 & 1.048 & $1.155^{* *}$ \\
\hline Diffbills_sometimes & $1.250 * * *$ & $1.270 *$ & 1.065 & $1.250 * * *$ & $1.266 * *$ & 1.035 \\
\hline Diffbills_never & $1.260 * *$ & $1.456 * * *$ & $1.317 * * *$ & $1.258 * *$ & $1.447^{* * * *}$ & $1.166^{*}$ \\
\hline $\mathrm{n}_{\text {country }}$ & 21 & 21 & 21 & 21 & 21 & 21 \\
\hline $\mathrm{n}_{\text {individual }}$ & 20,419 & 20,419 & 20,419 & 20,419 & 20,419 & 20,419 \\
\hline
\end{tabular}

Note: Displayed are the odds ratios; ${ }^{* * *} p<0.001 ;{ }^{* *} p<0.01 ;{ }^{*} p<0.05$; reference categories are Not_working and Diffbills_mostly. 
Table 5

Results of the multi-level models for sport and physical activity excluding walking

\begin{tabular}{|c|c|c|c|c|c|c|}
\hline & Model 3.1 & Model 3.2 & Model 3.3 & Model 4.1 & Model 4.2 & Model 4.3 \\
\hline & Sport_below & Sport_meet & Sport_exceed & Sport_below & Sport_meet & Sport_exceed \\
\hline Intercept & $0.078 * * *$ & $0.066 * * *$ & $0.272 * * *$ & $0.046 * * *$ & $0.050 * * *$ & $0.244^{* *}$ \\
\hline Govtqual & $1.406 * *$ & $1.561 * * *$ & $2.020 * * *$ & --- & --- & --- \\
\hline Govtqual_res & --- & --- & --- & 1.289 & $1.719 * *$ & $3.144 * * *$ \\
\hline GDP_pc & --- & --- & --- & $1.000 * *$ & $1.000 * * *$ & $1.000 * *$ \\
\hline Health_exp & --- & --- & --- & 1.021 & $1.045 *$ & 1.008 \\
\hline Edu_exp & --- & --- & --- & 1.113 & 1.042 & 1.101 \\
\hline Male & $0.819 * * *$ & 0.970 & $1.624 * * *$ & $0.819 * * *$ & 0.968 & $1.627 * * *$ \\
\hline Age & $1.028 * * *$ & 1.004 & 0.995 & $1.028 * * *$ & 1.004 & 0.995 \\
\hline Age_sq & $1.000 * * *$ & $1.000 * *$ & $1.000 * *$ & $1.000 * * *$ & $1.000 * *$ & $0.999 * *$ \\
\hline Relationship & 1.047 & 0.988 & $1.145^{* * *}$ & 1.047 & 0.990 & $1.146 * * *$ \\
\hline Kids_u10 & 1.011 & 0.960 & $0.863 * * *$ & 1.010 & 0.961 & $0.862 * * *$ \\
\hline Kids_1014 & 0.990 & $1.193 *$ & 0.990 & 0.990 & $1.193 *$ & 0.990 \\
\hline Self-employed & $0.785 * *$ & 1.068 & $1.441 * * *$ & $0.784 * *$ & 1.066 & $1.444 * * *$ \\
\hline Employed & 0.902 & 1.078 & $1.155^{* *}$ & 0.902 & 1.078 & $1.155^{* *}$ \\
\hline Diffbills_sometimes & $1.266^{* * *}$ & $1.224^{*}$ & 1.037 & $1.268 * * *$ & $1.222 *$ & 1.036 \\
\hline Diffbills_never & $1.339 * * *$ & $1.590 * * *$ & $1.168 *$ & $1.340 * * *$ & $1.587 * * *$ & $1.166^{*}$ \\
\hline $\mathrm{n}_{\text {country }}$ & 21 & 21 & 21 & 21 & 21 & 21 \\
\hline $\mathrm{n}_{\text {individual }}$ & 20,419 & 20,419 & 20,419 & 20,419 & 20,419 & 20,419 \\
\hline
\end{tabular}

Note: Displayed are the odds ratios; ${ }^{* * *} p<0.001 ;{ }^{* *} p<0.01 ;{ }^{*} p<0.05$; reference categories are Not_working and Diffbills_mostly. 